Historic, Archive Document

Do not assume content reflects current scientific knowledge, policies, or practices. 


\section{DESCRIPTIVE PRICE LIST}

जutsidas of

The Pines Plantation

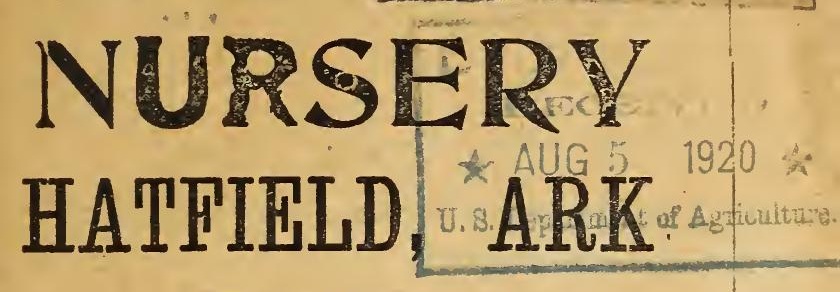

FRUIT TREES

BERRY PLANTS

GRAPE VINES

GARDEN PLANTS

NUT TREES

SHRUBBERY

FLOWERS

BULBS

Etc.

Best adapted to our soil and climate

TOTICE

ALL TREES

※TEN CENTS EACH IS THE PINES PLANTATION IATFIELD. ARKANSAS. 


\section{ASSURTMENTS}

F the convenience of busy people or those who are in doubt about what variety we have made up the following assortm ats from our best trees with a view of havi I? the longest possible season of good fruit. Yon heve the benefit of our knowledge and experience in these assortments.

APPLE TREE ASSORTMINT

T\&N nice tre ss Junэз Pippins Fall and? Winter. apples. This assortment $1.0 \mathrm{~J}$

\section{PEACH TREE ASSORTMENT}

TEN thrifty trees ripening May to Nov. but wo make up this assortment according to your frot period. these ten trees 1.00

\section{MIXED For Town Lot etc.}

Two Apple two Pear two Peach two Plum two Cherry one large Grape. 1.00 Of up right growth for closer planting .

\section{GRAPE VINES 1.00}

This assortment consists mostly of that old black favorite 'the Concorl. There are also several of the red and white sorts.

MODEL ORCHARD FOR 5.00

IN this we have 20 nice apple trees 4 to 6 feet high. 10 Peach all season, good sorts.

5 Plums American, European, and Jap, 5 Pear Keiffer, Seckel, Ea. Harvest etc 5 Cherry large red, black, etc. 3 to 4 sorts. 5 Grapes 3 black 1 large red 1 large white. 400 Strawderry plants early' midseson, late This assortment of labeled trees and plants $5.00 \mathrm{We}$ include a numder of extras free. 


\section{PEACH}

Listed about as they ripen, trees 3 feet and up MAYFLOW CARIHEN. A regalir eary beure:nice nuit. -CRAWFORDS. Ear,y and late.buth goud.

BELLE of GA. A good all purpose peach. ELBERTA. Large yellow, fine not sure.

SALWAY. Yellow . reliable; late bioomer, OCTOBER. Krummels and Bilyeau both fine. A few of other sorts but not enough to list ask.

\section{MISCELLANEOUS}

Butter-Nut or white walnut branched $2 \mathrm{ft}$. up Pecans, 12 to 18 inches, best Texas varieties

Orange seedling,does well here bush andwhip Any the adove trees Ten Cents Each. Asparagus and Horseradish roots 1et. each. Rhubarb, black or red Raspberries 10 for 25c. We have Sage Hops Tobacco \&gard̉en plant . we have have Dahlias Canna, Gladiolas etc.

\section{Nursery Inspeecticn 1010}

This tg tn Certify. Ihat im accoldance with the prcvisons of the Ark. i lant A it of 1' If $^{7}$ the nuisely and premises thereof belonging to The l'jnes fiantalion of Hatfield Ark, have $\mathbf{s}$ en inspecterl by a duly authos ized i spector and found to be substantially free fre $m$ dang -erous inscet pasts aub ci:erse and that the owner or operator of snch nursery has agreed to comply with requirsments as the Chief Inspector has prescribed for the elimination of infested tiees or plants as a condition of the issuance of this efrificate', and that nursery stock mar be soId and shir ped from! said nurseryunder this certificate or a copy there of until this certificato shall have expired or been revo= bed for cause. Not Transferat!. J. Jink. Trinitt. 


\section{IN FURHATHON}

SHIPPING The special low rate makes it as a rule, sheaper and at this tim?, perhap 3 better to ship nursery stock by express. Wha no instructions are given we will use our best judgment in forwarding.. we deliver trees in good condition to the transportation $\mathrm{Co}^{\prime} \mathrm{s}$. where our liability ceases.

WRITE Your name postoffice, freight station, and express of fice. yery plain.

W GUARENTEE vitality, variety, etc, to its purchase price only beyond that amount we will at no time or for any cause be responsible. But we exercise every care andhave yet to hear the first complaint.

CLAIMS Make claims for loss. shortage etc. at once please, so much easier to trace.

BUY THRIFT STAMPS, with your money if you t rink your fruit trees cancare for themselves, an uncared for planting of young trees is a reproach to you, to your nurseryman, to our tree inspectors, to your locality, and it $i_{1}$ jures the states fruit prospects. Culivate.

REMIT Any way way most convenient Draft, Check, or M. 0. For a small deposit we will at once set aside your order and ship when you are ready. ORDER EARLY.

\section{THE PINTS PLANTATION}

JAMES A. SLOTE, PROP.

$=$

MATFIELD. ARKANSAS.

\section{SIRAWBERRIES}

OUR BEST Early, Midseason, and Late also our splenid early large, mellow berry 25c. 100 We have a long season assortment of the best, 400 for 1.00 Our berries have never failed. We have Excelsior, Klondike, Aroma, and St. Louis. We want you to ask questions. 



\section{PEAR}

All pears seen adapted to our soil and climate, bight is the pears worst enemy, we

plint only the most resis int varieties.

KEIFFER,- Tree a strong grower bears young, pick about two weeks before eating.

SECKLE. - Finest flavored known, hardy, healthy, but slow growing tree.

SUGAR,- Or Sand pear a semi wild sort on its own root stands neglect, moreblight resistant then even seckle or keiffer.

EARLY HARVEST,-Golden yellow good for kitchen or market. Our pəar trees are 3 to 4 feet staignt or branched fine trees.

\section{CHERRIES}

EARLY RICHMOND,- Red, juicy,does well ripens here in May. a money maker.

MONTMORENCI,- Very large red middle to last of May. we have 500 bearing of the abve sorts and they are early money makers.

ROCKY MNT.- or Sand cherry bush form bears first or second year. fruit large dark somewhat puckery fine for cooking jams etc, We also have E.Morello, Tartarian Wood etc.

\section{PLUMS}

SHROP. DAMSON,-'Large blue plum JAPANESE,- ABUNDANCE-WICKSON, BURBANK and RED JUNE.

EARLY JUNE,- Large red juicy our best and surest mouey getter does best on own roots which bother some about sprouting when plow cuts the roots, sprouts come true.

\section{GRAPES}

CONCORD-The old favorite large black. NIAGARA-The white concord large whit DIAMOND-Fine, large, greenish white. AGAWA M-Large red. high flavor, f $\jmath \pi j$. ELVIRA-bunch compact yellowish sweet. ALL GRAPES FIVE CENTS EACH. 


\section{APPLE}

Listed about as they ripen -

ED JUNE - A heavy annual cropper for use and first ozrly money. Our cuttings mais are $f: 0 n$ the bes't:e? in so!k Co.

YELLOW HARV TU - Warly sweet very ow easiy bruiced ship scmewnet green RED ASTRACHAN - Largy juicy cook or market Tree strong grower large leaf YELLOW TRANSPARENT - Sub acid a y maker very early plant some.

HORSE - A great southern apple s ure. O F RIVER - T. lar; last ppe, AANO - A large dark red apple regular aby trees are from the bast of their kind. OELICIOUS - Hardy, bears young finest. ROME BEAUTY - Large striped strong er if frozen will bloom again yood keeper. ARK. Black - Firm juicy long keeper. NIne SAP Staymens Improved Larger a. long keeper getting best about christmas

We have ailso a few of the.following old favorites, - Ben Davis, yates, Sweet June inl Shockldy, York, grimes Golden etc.

nt most apple trees $30 \mathrm{ft}$. apart, dig the wide and deep, fill in with top soil'do no. $d$ up, keep the soil loose, A fork full of re to a tree each year will feed them nicely care of your trees whilc they are young hey will care for you when you are o!d.

We are growers,shippers, and canners of , we have tried out many sorts some pronprofitable, if in doubt about what sorts nt for home or market, ask us or some y grower or, better still,write to the lent of the State Plant Board Little, Rock J. LEE HEWITT who will without chare the states best information on any of fruit prodlems. 